\title{
Mental Health Services
}

In the Bulletin of July 1987 accounts from readers on how the transition from institutions is proceeding in a particular area were requested.

A report on five years' experience of the resettlement from hospital of mentally handicapped people in Leeds is presented.

\section{The Resettlement of People from a Hospital for Mental Handicap}

\author{
D. A. SPENCER, Consultant Psychiatrist, Meanwood Park Hospital, Leeds
}

This report presents an analysis of the resettlement of 54 mentally handicapped in-patients from Meanwood Park Hospital, Leeds during a five year period from mid-June 1982 to mid-June 1987.

\section{Selection and criteria for resettlement}

The patients for resettlement were proposed by the nursing staff who knew them well, in consultation with their parents and relatives, and the consultant psychiatrist, psychologist, social worker and occupational therapist involved in their care. Criteria applied were that the people chosen had expressed a wish to leave hospital, were willing to cooperate in and were likely to benefit from rehabilitation for life outside hospital.

The selection of patients was assisted by particulars gained from two surveys of the dependency of patients in Meanwood Park Hospital. One had been carried out in 1979 by the National Development Team for Mentally Handicapped People. Information had been collected using the one page Mental Handicap Register Form developed by the Health Care Evaluation Research Team (HCERT) in Wessex and was used to classify patients into one of four dependent groups. In 1980 the Leeds Joint Care Planning Team had funded a second more detailed replication of the Development Team's survey.

During the period under review one consultant psychiatrist wascovering the mental handicap services for Leeds so there was consistency in the selection and preparation of the patients.

Sex and numbers

In the five years 1982-1987, 54 patients (30 males, 24 females) were resettled. They represent one in eight of the hospital's population over this period. (Table I)

Recent policies not to admit long-stay children to mental handicap hospitals had resulted in a falling number of inpatients under 16 . The few remaining were priority cases for resettlement. Men and women in the older age groups who wanted to leave hospital were encouraged to do so on the grounds that they deserved the chance of a life in the community while they were still fit and able to accept the challenge. Thirty-five of the patients resettled were in the 30-59 age span. This reflected the high proportion of residents at the hospital within this middle age range. (Table II)

The 54 patients had spent altogether 1643 years in hospital, an average of over 30 years. The 24 women had spent 655 years, average 27.3 years, the men, 988 years, average 32.9 years. Two young patients resettled had both spent less than a year in hospital. (Table III)

(The +1 refers to an additional patient who went to a group home to a vacancy created by a resident moving to other accommodation in the community.)

As far as possible in the process of resettlement the accommodation provided was suited to the needs and wishes of the individuals who were prepared in compatible groups. One two-person group home was modified for physically disabled people. The one-person homes were for two who preferred to live alone. (Table IV)

As a result of the continuing rehabilitation programme over previous years few mildly mentally retarded patients remained in the hospital. Those selected for resettlement were people who had improved in hospital and had potential for discharge. Among the severely and moderately mentally retarded groups in the hospital were patients who had learned self-help skills and achieved a social competence necessary for resettlement. Many of those resettled had been designated 'imbeciles' or 'feeble-minded' in the terminology of 30 years ago.

\section{Medical conditions}

Down's Syndrome was the diagnosis most frequent in the group resettled. Nine (three male and six female; one in six of the people resettled) had this condition. In others the cause of their mental retardation was non-specific. Nine patients (six male, three female) suffered from epilepsy, a frequency of one in six, and less than the one in three to one in four typically found in a sample of in-patients. Their epilepsy was satisfactorily controlled by medication. None of the patients had active mental illness or serious degrees of challenging behaviours. A few patients were suffering from residual mental illness for which they continued to take antipsychotic drugs. On leaving hospital the patients resettled were registered with local family doctors. 
TABLE I

Age distribution at time of resettlement

Sex/number/age ranges

\begin{tabular}{lcccccccccc}
\hline & $\begin{array}{c}\text { Under } \\
16 \text { years }\end{array}$ & $16-19$ & $20-29$ & $30-39$ & $40-49$ & $50-59$ & $60-69$ & $70-79$ & Totals \\
\hline Male & 1 & 0 & 1 & 6 & 11 & 4 & 4 & 3 & 30 \\
Female & 1 & 1 & 5 & 2 & 4 & 8 & 2 & 1 & 24 \\
TOTAL & 2 & 1 & 6 & 8 & 15 & 12 & 6 & 4 \\
\hline
\end{tabular}

TABLE II

Time previously spent in hospital

Sex/number/years in hospital

\begin{tabular}{lcccccccc}
\hline & $\begin{array}{c}\text { Under } \\
10\end{array}$ & $10-19$ & $20-29$ & $30-39$ & $40-49$ & $50-59$ & $60-69$ & Totals \\
\hline Male & 10 & 3 & 7 & 8 & 3 & 5 & 1 & 30 \\
Female & 3 & 3 & 8 & 3 & 3 & 0 & 24 \\
TOTAL & 6 & 6 & 15 & 11 & 6 & 5 & 2 & 54 \\
\hline
\end{tabular}

TABLE III

Types of community placements

Sex/number/type of community placement

\begin{tabular}{|c|c|c|c|c|c|c|}
\hline \multirow[b]{2}{*}{ Type } & \multirow[b]{2}{*}{ I Person } & \multicolumn{2}{|c|}{$\begin{array}{c}\text { Community houses } \\
\text { (group homes) }\end{array}$} & \multirow[b]{2}{*}{4 Persons } & \multirow{2}{*}{$\begin{array}{c}\text { Private } \\
\text { residential } \\
\text { accommodation }\end{array}$} & \multirow[b]{2}{*}{ Total } \\
\hline & & 2 Persons & 3 Persons & & & \\
\hline Number of homes & 2 & 2 & 3 & 7 & 2 & 16 \\
\hline \multicolumn{7}{|l|}{ Residents numbers } \\
\hline Male & 1 & 3 & 4 & $16+1$ & 5 & 30 \\
\hline Female & 1 & 1 & 5 & 12 & 5 & 24 \\
\hline TOTAL & 2 & 4 & 9 & $28+1$ & 10 & 54 \\
\hline
\end{tabular}




\begin{tabular}{lccccc} 
Intellectual & $\begin{array}{c}\text { TABLE IV } \\
\text { categorisation-mental } \\
\text { ICD 9) }\end{array}$ & retardation & (Using \\
& \multicolumn{5}{c}{ Sex/number/mental retardation ICD9 } \\
\hline Category & Profound & Severe & Moderate & Mild & Totals \\
\hline $\begin{array}{l}\text { Numbers } \\
\text { Male } \\
\text { Female }\end{array}$ & 1 & 7 & 13 & 3 & 24 \\
\cline { 2 - 6 } Totals & 5 & 20 & 23 & 6 & 54 \\
\hline
\end{tabular}

\section{Service arrangements}

The resettled patients received the various social security benefits to which they were entitled. Those who were attending Adult Training Centres from the hospital continued to do so after discharge. For others arrangements were made for them to come to the hospital for any necessary day care pending the provision of more alternative day facilities by the Social Services. The group homes had support from NHS nursing and care staff, their numbers and hours of duty being related to the needs and dependency of the residents. SENs and care assistants covered the less dependent residents. A nurse RNMH was in charge of each group home for the highly dependent. The staffing was supervised and co-ordinated by a nursing officer.

\section{Comments}

For the patient resettled, sex, age, intelligence, time previously spent in hospital, medical condition, and the presence of epilepsy, were not themselves contra-indications to discharge from hospital. Crucial factors in resettlement emerged as the adequacy of accommodation, staff support, available day care, the social accomplishments of the patients in terms of their ability to live alone or in a small group in the community, and a freedom from behaviour likely to disturb, distress or frighten members of the public.

\section{Progress}

The greatest anxiety about resettlement was expressed by the relatives of patients for whom the hospital had been home for years, and where they appeared to be happy with friends and with occupational leisure facilities which had gradually improved enormously. The disadvantages of the group homes were isolation, distance from services, lack of open space and breakdowns in staff cover. Many parents, relatives and hospital staff viewed the resettlement process as a concession to policy and philosophy without their being inflexibly committed to it and, although some mentally handicapped in-patients could be resettled successfully, they feared that the deliberate closure of hospital resources would be a pyrrhic victory.

\section{New Publications}

Child Sexual Abuse is one of a series of Research Briefings prepared by the Economic and Social Research Council (ESRC) intended to inform policy makers and others involved in the key issues of the day about the findings of recent social science research. This review by Professor $\mathrm{La}$ Fontaine examines the implications of research findings for current policy and provides an informed context for the debate on child abuse.

Enquiries to: Chris Caswill, Director of Information, Economic and Social Research Council, 160 Great Portland Street, London WIN 6BA (telephone 01-637 1499, extension 279) or Professor Jean La Fontaine, 14 Addington Square, London N1 (telephone 01-708 4496).

Neuropsychopharmacology is the official publication of the American College of Neuropsychopharmacology and features the newest advances in research studies and developments in clinical treatment for a variety of psychiatric disorders that can be treated using pharmacologic agents. Emphasis is given to reports of original research that integrate basic and clinical science; selected review articles are also considered.

Enquiries regarding manuscript submission: Dr J. Christian Gillin, Editor-in-Chief, Neuropsychopharmacology, Department of Psychiatry, University of California, San Diego, Psychiatric Service (V-116A), San Diego Veterans Administration Medical Center, 3350 La Jolla Village Drive, San Diego, California 92161, USA. Subscription enquiries: Elsevier Science Publishers, PO Box 211, 1000 AE Amsterdam, The Netherlands. 